\title{
CULTURA CORPORAL DE MOVIMENTO E CELULAR: IMPLICAÇÕES NA PARTICIPAÇÃO DOS ALUNOS NAS AULAS
}

\author{
BODY CULTURE OF MOVIMENT AND CELLULAR: \\ IMPLICATIONS IN THE PARTICIPATION OF STUDENTS IN CLASS
}

\author{
CULTURA CORPORAL DE MOVIMIENTO Y CELULAR: \\ IMPLICACIONES EN LA PARTICIPACIÓN DE \\ LOS ALUMNOS EN LAS CLASES
}

\begin{abstract}
Jederson GARBIn TENÓRIO ${ }^{1}$
LuCAS DE ANDRADE CARVALHO ${ }^{1}$ Universidade Metodista de Piracicaba (UNIMEP), Piracicaba/SP - Brasil ${ }^{1}$
\end{abstract}

Resumo Este trabalho objetiva propor reflexões sobre as implicações de hábitos relacionados às tecnologias, em especial, a utilização dos celulares, nas aulas de Educação Física (EF). É percebido o aumento do uso de celulares, como uma ferramenta indispensável na vida das pessoas para além de uma "simples" ligação telefônica. No entanto, pessoas de todas as idades utilizam aparelhos celulares, modificando modos de interagir com o meio que as cerca. Como procedimentos metodológicos realizamos uma pesquisa bibliográfica eminentemente qualitativa tecendo um diálogo com os temas: Educação Física, celular, não-participação nas aulas e contemporaneidade. Podemos compreender que o celular se consolida como algo que pode rivalizar com as aulas de EF, que tem na cultura corporal de movimento, elementos que sublinham sua especificidade. Diante disso, faz-se necessária uma reflexão acerca da maneira como essa ferramenta tem adentrado o espaço da escola trazendo implicações na participação dos alunos nas aulas.

Palavras-chave: Educação Física; Celular; Não-ParticipaÇão.

Abstract This work aims to propose reflections on the implications of habits related to technologies, especially the use of cell phones, in Physical Education (PE) classes. Increased use of mobile phones is perceived as an indispensable tool in people's lives beyond a "simple" phone call. However, people of all ages use cellular devices, modifying ways of 
interacting with the environment around them. As methodological procedures, we carried out an eminently qualitative bibliographical research through a dialogue with the themes: Physical Education, cellular, non-participation in classes and contemporaneity. We can understand that the cell consolidates as something that can rival the EF classes, which have in the body culture of movement, elements that underline its specificity. Therefore, it is necessary to reflect on the way in which this tool has penetrated the space of the school bringing implications in the participation of the students in the classes.

Key-words: Physical Education; Cell phone; Not-Participation.

Resumen Este trabajo objetiva proponer reflexiones sobre las implicaciones de hábitos relacionados a las tecnologías, en especial, la utilización de los celulares, en las clases de Educación Física (EF). Se percibe el aumento del uso de celulares, como una herramienta indispensable en la vida de las personas más allá de una "simple" llamada telefónica. Sin embargo, personas de todas las edades utilizan aparatos celulares, modificando modos de interactuar con el medio que las rodea. Como procedimientos metodológicos realizamos una investigación bibliográfica eminentemente cualitativa tejiendo un diálogo con los temas: Educación Física, celular, no participación en las clases y contemporaneidad. Podemos entender que el celular se consolida como algo que puede rivalizar con las clases de $\mathrm{EF}$, que tiene en la cultura corporal de movimiento, elementos que subrayan su especificidad. Por eso, se hace necesaria una reflexión acerca de la manera como esta herramienta ha adentrado el espacio de la escuela trayendo implicaciones en la participación de los alumnos en las clases.

Palabras clave: Educación Física; Teléfono celular; No participación.

\section{INTRODUÇÃo}

Com o início da Revolução Industrial ocorrida no século XVIII, surgem mudanças advindas dos progressos tecnológicos que trouxeram hábitos sociais e estilos de vida, delimitando as cargas de trabalho, representando maiores possibilidades do usufruto do tempo disponível.

Na contemporaneidade, de acordo com Harvey (1989) a produção capitalista trouxe como consequência a aceleração da circulação de mercadorias e do consumo, acentuando a volatilidade de processos de trabalho, da moda, de ideias e de práticas de lazer. Estas características do mundo moderno tencionaram com experiências que eram consideradas comuns, que foram substituídas por vivências associadas, muitas vezes, ao consumo, ao supérfluo e ao efêmero.

As experiências e hábitos de vida que fazem parte do nosso cotidiano estão altamente associadas à sociedade capitalista e ao consumo exacerbado. Nessa direção, os sujeitos são induzidos a consumir todo tipo de produto, passando a produtos materiais (aparelhos celulares, óculos, calçados) até o próprio corpo tornou-se um objeto a ser "reformado", com a

Comunicações | Piracicaba | v. $26 \mid$ n. $1 \mid$ p. 309-325| jan.-abr. 2019 
busca de cirurgias estéticas, tratamentos capilares, dermatológicos etc. Para Harvey (1989), signos, imagens e discursos são propagados como se fossem mercadorias, levando os sujeitos a sofrerem um "bombardeio de estímulos", que fazem que as pessoas tenham contato com produtos inovadores a todo momento. Esse fenômeno provoca a sensação de alegria diante da aquisição de um objeto novo, fomentando o descarte, muitas vezes prematuro de bens de consumo. Não importa que o produto seja algo concreto, pois os mecanismos de envolvimento são cada vez mais sutis e ao mesmo tempo eficientes.

$\mathrm{O}$ ambiente urbano facilita claramente esse sistema, sendo povoado de estratégias de marketing, como se a felicidade e a satisfação somente pudessem ser alcançadas à medida que as pessoas possam adquiram aquilo que se vende, que está em evidência, que tem maior exposição frente aos sujeitos consumidores. A aquisição de uma mercadoria ou padrão de beleza passa a ser parte integrante na busca de afirmação social, auto realização e significado na vida (HARVEY,1989). Nesse sentido, os aparelhos celulares são canais que se conectam em redes sociais (whats app, facebook, instagram), além de sites de compras, games e diversos aplicativos etc.

Essas ferramentas ocupam um espaço considerável na vida das pessoas na contemporaneidade, constituindo tanto opção de trabalho, quanto podem ser explorados como conteúdos culturais do lazer. Os aparelhos celulares podem ser uma espécie de ponte para a busca de status ou sinalizar diferenças sociais, além do sentimento de pertencimento a determinado grupo, que acaba concorrendo com instituições que até então, eram tidas como tradicionais, como a família, a igreja e a escola. Como consequências, alguns valores, normas e hábitos começam a serem fragilizados conforme o contexto visualizado. Para Brunhs (1999), alguns elementos importantes da humanidade, como a convivência e a comunicação foram fragilizados em detrimento de modernos hábitos e estilos de vida.

No que se refere à escola e EF, percebemos empiricamente ao longo do exercício do magistério, um aumento do desinteresse pelas atividades propostas ao visualizar os alunos utilizando aparelhos celulares (para envio de mensagens, assistência a vídeos, troca de mensagens), tendo muitas vezes, que serem chamados a participar das aulas vivenciais, quando os mesmos se dirigem rapidamente para as arquibancadas da quadra para acessarem o aparelho, gerando um "conflito" de interesse entre "aula x celular". Esse é tido como o problema central da presente discussão, que permeia nosso cotidiano docente que, conforme Minayo (2001, p. 17): "[...] nada pode ser intelectualmente um problema, se não tiver sido, em primeiro lugar, um problema da vida prática".

Para Harvey (1989), a sociedade do descarte representa não somente jogar fora valores, mas também estilos de vida, relacionamentos estáveis. Nesse sentido, essa aceleração de trocas golpeou experiências comuns cotidianas dos sujeitos. Na escola, comportamentos e atitudes tidas como tradicionais também foram modificados na contemporaneidade e a aula de EF, antes a preferida pelos alunos que consideravam o dia da semana mais esperado, porque jogavam, se divertiam e hoje, para alguns pode ser uma espécie de "fuga" da rotina escolar, podendo ser espaço para, por exemplo, utilizar o aparelho celular.

Conforme Libâneo (1994), o processo educativo é sempre contextualizado socialmente, havendo uma subordinação à sociedade que estabelece interesses de ordem política, 
econômica e cultural. No entanto, é importante sublinhar que as relações sociais que ocorrem na sociedade não são permanentes e estáticas.

Ao perceber essas questões, nossa análise se direciona para as aulas de EF considerando valores e conhecimentos que se "conectam" em aspectos mais abrangentes inseridos na escola e na sociedade contemporânea.

\section{MÉTodo}

Como procedimento metodológico foi realizado um levantamento bibliográfico sobre os temas (juntos ou separados): Educação Física escolar, celular, não participação e contemporaneidade, ancorados em alguns autores, como: Harvey (1989), Bracht (1999), Betti (2003), Daolio (2006), Nagumo (2014), caracterizando uma pesquisa eminentemente qualitativa. Nessa fase, por se tratar de uma pesquisa bibliográfica, consideramos as ideias de Severino (2007, p. 122) que a descreve como sendo: “[...] aquela que se realiza a partir do registro disponível, decorrente de pesquisas anteriores, em documentos impressos, como livros, artigos, teses etc". Esse levantamento bibliográfico é base para a discussão do problema investigado e também para a construção do referencial teórico que deu fundamentação para algumas considerações. -

A finalidade da pesquisa bibliográfica é acessar produções científicas disponíveis sobre um determinado tema, caracterizando um tipo de análise que corresponde às pesquisas qualitativas. Para Minayo (1994, p. 21-2) esse tipo de pesquisa:

\footnotetext{
(...) responde a questões muito particulares. Ela se preocupa, nas ciências sociais, com o nível de realidade que não pode ser qualificado. Ou seja, ela trabalha com o universo de significados, motivos, aspirações, crenças, valores e atitudes, o que corresponde a um espaço mais profundo das relações, dos processos e dos fenômenos que não podem ser reduzidos à operacionalização de variáveis.
}

Em relação ao tratamento das obras que são referência para este trabalho, apoiamo-nos nas diretrizes para leitura, análise e interpretação de textos, de acordo com Severino (2007):

1. Análise textual, que consiste em buscar informações a respeito do autor do texto e verificar o vocabulário, os fatos históricos apresentados pelo texto, com a possibilidade de exibir uma esquematização do mesmo, a fim de propiciar uma visão de conjunto da unidade;

2. Análise temática que procura ouvir o autor e apreender, sem intervir no conteúdo da mensagem apresentada pelo autor, fazendo ao texto uma série de perguntas, sendo que as respostas fornecem o conteúdo da mensagem;

3. Análise interpretativa, em que se busca uma compreensão interpretativa das ideias apresentadas pelo autor. Nesse tipo de análise compreende-se também a crítica, a formulação de um juízo crítico, de tomada de posição; 
4. A problematização, que se trata de um tipo de abordagem com vistas ao levantamento dos problemas para a discussão;

5. A quinta e última etapa trata-se da síntese pessoal, da construção lógica de uma redação, de modo a dar condições ao estudioso de progredir no desenvolvimento das ideias do autor.

O referencial teórico deste trabalho está ancorado em autores da Educação e EF. O levantamento bibliográfico ocorreu do mês de junho ao mês de setembro de 2018.

\section{O USO DO CELULAR E A CONTEMPORANEIDADE}

A Contemporaneidade é considerada como período histórico cujo início está ligado à Revolução Francesa (1789), tendo aproximações com o desenvolvimento do capitalismo e, como consequência as potências europeias disputam espaço no mercado consumidor, buscam novos territórios e matérias-primas. Nesse contexto, o trabalho e a produção sofreram de um processo de intensificação, acelerando o tempo de giro de mercadorias fomentando maior consumo. Ou seja, os sistemas aperfeiçoados de comunicação, associados à racionalização das técnicas de distribuição, aumentaram a velocidade de circulação de mercadorias (HARVEY, 1989). Para o autor supracitado, como consequência dessa aceleração, acentuou-se a "efemeridade" e "volatividade" da moda, produtos, técnicas de produção etc.

Esse aumento na expansão e no ritmo de consumo tem implicações também em uma gama de estilos de vida, com comportamentos e valores modificados constantemente em função dos produtos criados. "Por intermédio desses mecanismos (altamente eficazes da perspectiva da aceleração do giro de bens no consumo), as pessoas foram forçadas a lidar com a descartabilidade, a novidade e as perspectivas de obsolência instantânea" (HARVEY, 1989, p. 258).

O aparelho celular é uma invenção moderna tendo sua popularização e utilização expandida fortemente com o acesso da internet à população em várias partes do mundo. $\mathrm{O}$ celular tornou-se um objeto (in)dispensável na vida das pessoas por possibilitar a realização de inúmeras tarefas que anteriormente eram feitas em objetos e locais separados, por exemplo: máquina fotográfica, aparelhos de televisão, computador, controle de ar-condicionado, lanterna, agências bancárias, agências dos correios, lojas de roupas, lanchonetes, etc. Portanto, os aparelhos celulares têm ocupado um tempo/espaço muito significativo no cotidiano das pessoas.

A TIC Domicílio (2017) aponta que no Brasil 83\% da população possui telefone celular, destes, $92 \%$ dos domicílios têm o aparelho em suas residências. Cerca de $65 \%$ dos jovens na faixa etária de 10 a 15 anos já acessaram celular. A faixa etária que mais utilizou a internet pelo celular foram os jovens dos 16 aos 24 anos, compartilhando conteúdos $(81 \%$ desta faixa). 
O Brasil possui cerca de 236.229.884 milhões de linhas de telefonia móvel ${ }^{1}$, ou seja, existem mais celulares que habitantes no país, dado que demonstra que o aparelho ocupa grande relevância na vida das pessoas.

O espaço criado com a utilização dos aparelhos é um lugar que se constitui de atividades sociais que podem favorecer os sentidos de pertencimentos simbólicos, econômico e supostamente afetivo.

Uma dependência no uso e modo de utilização desses aparelhos tem reflexos na escola e por conseguinte no processo educativo com obstáculos a serem superados em função da existência de um espaço virtual que pode se opor ao espaço real.

Os alunos na escola, ao se conectarem na internet via aparelho celular podem estar em um espaço virtual, muitas vezes, que não corresponde àquilo que vivenciam no cotidiano. Nesse contexto, os jovens constroem uma dinâmica social resultante do uso do celular que contribui na formação de identidades pertencentes à cultura juvenil, podendo se afirmar socialmente com signos e símbolos específicos que não o da linguagem formal ensinada na escola, por exemplo. Essa linguagem extrapola a escrita, sendo também parte da linguagem corporal, que envolve um sistema de representação simbólica.

Nessa fase da escolaridade e das próprias características pertencentes a essa idade, os adolescentes começam a adotar uma vida mais autônoma em relação à dependência familiar e se inserem na dinâmica social com responsabilidades relacionadas ao trabalho, estudos, grupos sociais que até então não faziam parte de sua rotina. De acordo com Dayrell (2003, p.43): "[...] cada um deles vai se construindo e sendo construído como sujeito: um ser singular que se apropria do social, transformado em representações, aspirações e práticas, que interpreta e dá sentido ao seu mundo e às relações que mantêm". Dessa maneira, a construção de conhecimentos é desenvolvida ou não nesse contexto em que o educando está inserido, considerando que ocorre o início de um maior protagonismo em espaços sociais, no lazer, no trabalho e na escola.

Em função deste significado de entretenimento e passatempo, vários jovens afirmam que a nova mídia também é tomadora de tempo. As longas horas conversando com os amigos pela rede, navegando na internet ou em jogos on-line e os levam a permanecer bastante tempo sob pouca atividade física diante do computador, e toma tempo que alguns deles acreditam que poderiam estar praticando outras atividades fora de casa, principalmente (BARCELOS, 2010, p. 195).

Surgem também nesse momento as contestações e as tensões frente à rotina escolar, as regras da instituição e aos modos como o professor conduz o processo, muitas vezes driblando as eventuais proibições das hierarquias escolares. Os jovens alunos apresentam certo reflexo de suas condições sociais, familiares e econômicas, podendo esse contexto interferir na aprendizagem de conteúdos que a escola oportuniza. "Contudo, mais decisiva é a influência

Informação obtida na página: http://agenciabrasil.ebc.com.br/geral/noticia/2018-03/cai-o-numero-de-linhas-de-celular-em-operacao-no-pais. Acesso em: 22 de setembro de 2018.

Comunicações $\mid$ Piracicaba $\mid$ v. $26 \mid$ n. $1 \mid$ p. 309-325| jan.-abr. 2019 
do contexto no qual a mídia é recebida quanto mais pobre o meio em que as crianças crescem, maior deve ser o receio perante o fenômeno da passividade" (BETTI, 2003, p. 50).

Como o celular transmite uma linguagem mediada geralmente pela grande mídia, a forma como os sujeitos interagem com o aparelho gera uma aprendizagem predominantemente superficial, fragmentada e parcial, muitas vezes, ligadas a interesses políticos e comerciais. Logicamente que a linguagem que se estabelece com o sujeito receptor é mediada por símbolos e signos, composta de letras coloridas, sons, figuras atrativas, favorecendo uma melhor atenção de quem visualiza, dando a impressão do sujeito estar diante de novidades e surpresas. Para Betti (2003, p. 38): “[...] a imagem dirige-se diretamente às potências concretas da presença no mundo, à sensibilidade, à imaginação e às paixões, que reagem de imediato às solicitações que são feitas". As imagens e linguagens utilizadas pelas mídias promovem uma sensibilização e emoção causando maior impacto em relação a um texto escrito.

Diante desse quadro e das modificações ocorridas na sociedade que tendem a invadir a escola é necessário que o processo ensino-aprendizagem seja marcado pela valorização da relação professor-aluno e a instituição escolar não seja reduzida e seduzida pelos modismos sociais, considerando que a escola tem o compromisso de oportunizar o acesso a conhecimentos sistêmicos construídos historicamente. Conforme nos esclarece Nóvoa (2007):

A pedagogia tradicional era baseada nos conhecimentos e na transmissão dos conhecimentos. A grande ruptura provocada pela pedagogia moderna foi colocar os alunos no centro do sistema. (...) Não se trata de centrar na escola nem nos conhecimentos, como advogava a pedagogia tradicional, nem nos alunos como advogava a pedagogia moderna, mas sim, na aprendizagem (NÓVOA, 2007, p. 6).

Compreende-se que a escola não deva negar a cultura do aluno, suas expectativas e hábitos valorizados, no entanto, é necessário ressignificar a cultura dominante, tensionando valores associados ao consumismo, status social e individualismo. De acordo com Luckesi (1994, p. 137-138):

A escola que queremos trabalhará no sentido de que crianças, jovens e adultos assimilem ativamente os conhecimentos (formando habilidades e hábitos) e adquiram convicções fundamentais de solidariedade e igualdade entre os seres-humanos, assim como hábitos de convivência, de luta, de trabalho, de conquista individual e coletiva.

Não que as TIC' $\mathrm{s}^{2}$ devem ser desconsideradas no processo ensino-aprendizagem. No entanto, não devem ser ferramentas predominantes. Além disso, a utilização das TIC's (o

2 Para Oliveira, Moura e Sousa (2015, p. 77) as TIC's são definidas como: “[...] um conjunto de recursos tecnológicos integrados entre si, que proporcionam por meio das funções de software e telecomunicações, a automação e comunicação dos processos de negócios, da pesquisa científica e de ensino e aprendizagem". Compreendemos que o celular é uma ferramenta de relação direta no que se refere às TIC's quando utilizada pedagogicamente no ambiente escolar. 
celular se insere nesse tema) não prescinde da mediação ou intervenção pedagógica do professor, conforme nos esclarece Luckesi (1994, p. 115): "Na práxis pedagógica, o educador é aquele que, tendo adquirido o nível de cultura necessário para o desempenho de sua atividade, dá direção ao ensino e à aprendizagem".

Por isso, os sujeitos aprendem melhor, mediados por outros sujeitos que possuem o domínio de determinados conhecimentos que possam conduzi-los para uma prática autônoma.

\begin{abstract}
Ou seja, a prática da liberdade prevê, por parte do educando, busca contínua ao saber, ao conhecimento, para que dele retire instrumentos para melhor compreender o mundo à sua volta, criá-lo e recriá-lo. Por parte do professor, a prática da liberdade prevê atenção aos aprendizes, compromisso com o desenvolvimento dos conteúdos e entendimento de que os seres humanos possuem limites que não se supera por si mesmos (CRUZ DE OLIVEIRA, 2010, p. 175).
\end{abstract}

É necessário que a escola não perca o foco na transmissão de conteúdos sistêmicos, com o necessário tratamento pedagógico, considerando que a adoção de tecnologias, por si só, não é capaz de promover uma auto-educação aos alunos. Ao considerarmos que o movimento da Escola Nova ainda tem grande influência na prática pedagógica no Brasil é relevante que alguns aspectos sejam criticamente considerados. "A teoria e prática escolanovistas se disseminaram em muitas partes do mundo, fruto certamente de uma renovação geral que valorizava a autoformação e a atividade espontânea da criança" (GADOTTI, 1993, p.142). Esse pressuposto buscava aproximar as aulas às expectativas discentes, quando destaca que a seleção dos conteúdos é propiciada aos alunos, entendidos como agentes da aprendizagem na qual escolhem aquilo que gostariam de aprender. O problema dessa perspectiva teórica é que ao ser traduzida para a escola, sua prática se mostra fragmentada e restrita, tendo como consequências uma ausência de intervenção, levando à falta de aprendizado dos alunos. Nesse caso, a liberdade pressupõe que os alunos não tenham a referência de um processo pedagógico mediado pelo educador. Na sequência, procuramos fazer uma aproximação desse tema com a cultura corporal de movimento ${ }^{3}$ problematizando questões contemporâneas da EF.

\title{
Cultura Corporal de MOVimento, Celular E PARTicipaÇão nas aUlas
}

Em termos de ensino, a disciplina de EF se apropria dos conteúdos da chamada cultura corporal de movimento, sendo vista de modo diferente de outras áreas do conhecimento que compõem o currículo escolar, por ter no corpo e no movimento, elementos predominantes. De acordo com Betti (2003, p. 19): “A educação física também propicia aos alunos, como os outros componentes, um certo tipo de conhecimento. Mas não é um conhecimento que se possa incorporar dissociado de uma vivência concreta".

3 Termo adotado para se referir aos conteúdos culturais que a EF trata, como os jogos, os esportes, as danças, as ginásticas e as lutas. Para Bracht (1999, p.15), a EF é a: “[...] prática pedagógica que tematiza com a intenção pedagógica as manifestações da cultura corporal de movimento". 
No entanto, a EF, embora seja a disciplina preferida da maioria dos alunos (BETTI e LIZ, 2003), precisa preservar sua especificidade que busca a participação dos alunos nas atividades vivenciais em uma perspectiva crítica. Tenório e Lopes da Silva (2015), ao investigarem sentidos e significados de alunos não participantes acerca das aulas de $\mathrm{EF}$, consideraram que eles gostavam do tempo e espaço das aulas, sem que isso significasse valorizar a disciplina, pois utilizam desse momento para usar o celular, conversar com os amigos, sair da sala etc. Segundo Darido (2004), ocorre um aumento gradativo do afastamento dos alunos nas aulas vivenciais de EF nas séries finais do Ensino Fundamental, sendo esse problema acentuado no Ensino Médio. Esse fenômeno pode ter estreita relação com o acesso dos alunos ao uso do celular, sendo observado que os alunos do Ensino Fundamental II pouco utilizam esse objeto de maneira frequente, podendo trazer implicações no modo como se apropriam da aula, gerando um aumento do número de alunos que não participam das aulas vivenciais. Os discentes, no Ensino Médio apresentam estratégias de "fugas" de um envolvimento mais efetivo da aula ao sentarem na arquibancada, conversar, ir ao banheiro, beber água, ou até mesmo "mexer" no celular. Tenório e Lopes da Silva (2013, p. 73-74): "[...] entendemos por não participação dos alunos nas aulas aquela conduta em que os alunos estão presentes, mas não participam do que é proposto pelo professor ou somente assistem ao que os outros realizam". A participação ou não nas aulas fica mais facilmente percebida na "quadra", embora esse problema não seja exclusivo da EF. Isso porque em outras disciplinas, quando os alunos ficam sentados nas carteiras, esse comportamento parece menos perceptível.

Para Tardif e Lessard (2011, p. 68): “[...] nada é mais difícil do que ensinar a alunos que não querem aprender, alunos que recusam não o professor, mas a escola em geral e o ter que estar ali”. A presença do celular, pode representar mais uma tarefa que cabe ao educador assumir, ao ter que se preocupar se o aluno está participando da aula, realizando as tarefas propostas ou prestando atenção na aula.

A utilização de aparelhos celulares dentro da aula de EF, tensiona com a finalidade da disciplina em viabilizar aos alunos o acesso ao conhecimento para que possam ter autonomia em relação às atividades físicas e esportivas nos momentos de tempo disponível (DAOLIO, 2006). Nessa mesma direção, Betti (2003, p. 19) reitera: “Assim, entendemos que a principal tarefa da educação física na escola é introduzir e integrar o aluno na cultura corporal de movimento...". Obviamente que os temas ligados à atividade física e ao esporte devem ser abordados de modo a ressignificar conhecimentos difundidos pelos meios de comunicação de massa. Como exemplo, além da utilização exacerbada do uso de celulares, outros temas podem ser explorados nas aulas como hábitos contemporâneos que têm impacto no tempo disponível das pessoas, como: "Ingestão em excesso de refrigerantes", "O consumismo em interface com as práticas corporais", "Mídia e padrão de beleza", dentre outros. Nesse sentido, o celular, com a devida condução do professor, pode ser utilizado como ferramenta de aprendizagem.

Considerando a EF como um tempo/espaço menos rígido no currículo escolar (CRUZ de OLIVEIRA, 2010), e a aula ser desenvolvida na quadra, há uma maior dificuldade do 
professor observar o que todos fazem. No entanto, ainda é possível que o professor exerça autoridade e que a aula seja um momento propício de participação dos alunos. Como pode o aluno não participar das aulas e gostar de jogar futebol no celular ou no vídeo game?. Por isso, a importância da cobrança do professor aos alunos que não participam no intuito de inseri-los nas atividades. Snyders (1978, p.8) considera que: “[...] a abdicação do mestre deixe os alunos serem vítimas de estereótipos estabelecidos, que uma certa indiferença pelos conteúdos do ensino e pela sua força de verdade condene os alunos a um ceticismo inevitavelmente passivo..." (grifos do autor).

Assim, embora a maioria dos alunos tenha certa preferência pelas aulas de EF, ao associarem a disciplina a uma maior liberdade, de modo diferente das outras disciplinas, é importante ao professor estar atento à presença de alunos na "periferia da quadra"4.

A seguir, exibimos duas figuras que ilustram diferenças em relação ao acesso dos alunos a cultura corporal de movimento, registradas no "chão da quadra", tendo diferencial a presença ou não do celular. A Figura 1 demonstra como a intervenção do professor em não permitir o acesso ao aparelho celular faz que os alunos se apropriem da atividade desenvolvida. A Figura 2 representa como os alunos podem ficar alheios ao processo educativo quando utilizam simultaneamente o celular no momento de aula.

Figura 1: Alunos do Ensino Médio vivenciando o Badminton.

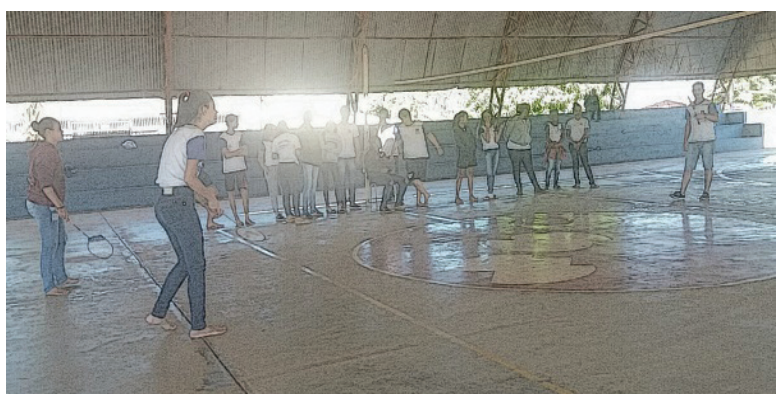

Figura 2: Alunos do Ensino Fundamental utilizando o celular durante a aula.

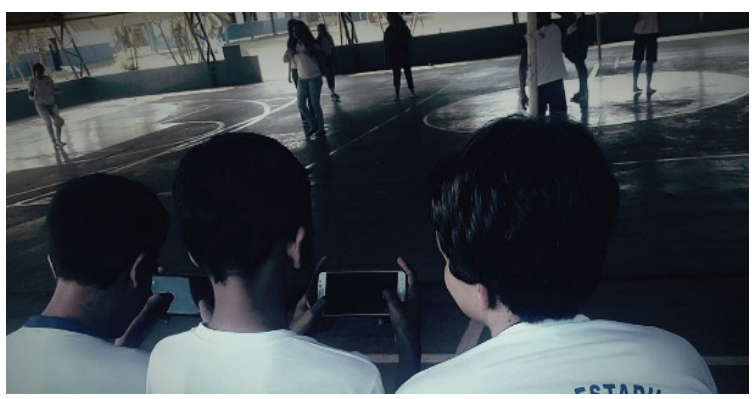

4 Expressão considerada por Cruz de Oliveira (2010), para representar um local utilizado pelos alunos para "driblar" a participação nas aulas. 
Ao buscarmos uma analogia acerca da vivência dos alunos nos conteúdos da cultura corporal de movimento, podemos construir uma aproximação entre "jogo virtual x jogo real" em interface com a teoria do jogo, quando Caillois (1990) em sua obra: "Os jogos e os homens: a máscara e a vertigem", defende que a vivência do sujeito em um jogo solitário, seja um video-game, um aplicativo, jogos de azar etc, não substitui o contato com outro sujeito corporalmente presente: "Dir-se-a faltar alguma coisa à atividade do jogo quando esta se reduz a um simples exercício solitário. Geralmente, os jogos só atingem a plenitude no momento em que suscitam uma cúmplice ressonância. Tem necessidade de presenças ativas e aderentes" (CAILLOIS, 1990, p. 61). O autor supracitado argumenta que jogar representa jogar com... jogar contra, pressupondo a companhia e não a solidão. Portanto, uma participação na aula, tem sentido quando os sujeitos vivenciam os conteúdos, interagem, se movimentam, não tendo relevância quando o mesmo só observa os colegas ou então ocupa um ambiente virtual sentado na arquibancada utilizando o celular.

No caso da EF, nada substituirá a vivência, o "se movimentar", ou seja, as possibilidades dos sujeitos participarem de práticas corporais. A especificidade do movimento na EF constitui paradigma da área que, inclusive a tornou historicamente valorizada pelos alunos e pela comunidade escolar (DAOLIO, 2006), que não deve ser secundarizada em função de novas tecnologias e hábitos.

Como a disciplina de EF é associada ao fenômeno esportivo, que diante das modalidades esportivas, que ocupam espaço no tempo disponível de muitas pessoas que assistem, leem ou conversam sobre o tema, sendo, portanto, espectadores, conforme Cruz de Oliveira (2010, p. 142): “[...] todo o privilégio de tematização que o esporte recebe na sociedade contemporânea acaba por refletir na EF escolar, pois em nenhuma outra disciplina escolar tal conhecimento é abordado".

O esporte é também parte de um conteúdo vivenciado no contexto do lazer, podendo ser tratado na escola como parte de uma educação para o lazer. Ao se tratar da educação para o lazer nas aulas de EF, podemos compreender que as aulas devem incentivar a prática de atividades em seu tempo disponível como hábito regular. Além disso, a formação de alunos, capazes de adotar uma postura autônoma e crítica para fora dos muros da escola, tanto na prática como na assistência, em relação às atividades físico-esportivas, não deve ser desconsiderada. Segundo Marcellino (2013), os conteúdos explorados nas aulas são utilizados pelos sujeitos, em seu tempo "livre" na maioria das vezes, como assistência, ou seja, vivenciam o lazer, assistindo ou contemplando os conteúdos culturais do lazer. Nesse gênero ${ }^{5}$ do lazer (assistência), consideramos a influência da mídia (e o celular tornou-se na atualidade talvez o principal instrumento) em sua divulgação, tanto no incentivo para a prática de atividades físicas e esportivas, como e principalmente em seu consumo, de diversos produtos que são fabricados e vendidos pela indústria esportiva, por meio de muitas modalidades esportivas.

5 Conforme Marcellino (2007) podemos considerar três gêneros do lazer (prática, assistência e conhecimento). $\mathrm{O}$ autor defende que, independente do gênero, o indivíduo pode desenvolver os conteúdos do lazer, de maneira "ativa" ou "passiva". Assim, pode-se superar os níveis conformistas, para críticos e criativos, oferecendo possibilidades de descanso, divertimento e de desenvolvimento pessoal e social. 
Experiências pedagógicas que utilizam o celular como ferramenta de aprendizagem que contribui para o desenvolvimento das atividades propostas durante as aulas podem ser encontradas em trabalhos como os de Tenório (2018), Carlan (2012), Mendes e Pires (2009) e Betti (2006). Esses trabalhos trazem consigo, metodologias pautadas em modelos de pesquisa-ação ou pesquisa participante em que os pesquisadores buscam uma aproximação entre teoria e prática, sendo agentes ativos no processo educativo.

Por exemplo, a Copa do Mundo de Futebol Fifa 2018, realizada na Rússia, trouxe como novidade para milhões de telespectadores, a utilização do VAR $^{6}$ durante as partidas e logo virou tema de roda de conversas entre pessoas das mais diversos níveis, afinal de contas, todo brasileiro é considerado um técnico de futebol, conforme destacado por Daolio (2006). Esses elementos presentes no esporte de alto nível têm reflexos na escola, que muitas vezes, "acolhe" práticas, gestos, signos e comportamentos na EF escolar.

Uma simulação em aula pode ser feita pelos alunos, ancorada nos trabalhos citados, como uma atividade que utilize o celular como ferramenta e posteriormente sendo feita uma discussão com os alunos acerca de possíveis aspectos presentes na decisão do árbitro, como tomada de decisão, trabalho em equipe, pressão psicológica do árbitro etc. Esse é só um exemplo de como pode ser a utilização "responsável" do celular com a condução do professor.

Portanto, aulas com temas que muitas vezes são veiculados por meio de um conhecimento acrítico e restrito, no caso, veiculado nos aparelhos celulares, podem ser oportunidade de ampliação e compreensão de conteúdos físico-esportivos, não se restringindo somente à aprendizagem de seu aspecto técnico, mas ao contexto mais abrangente onde possam estar inseridas, "[...] não só no sentido de vivenciá-la, mas também compreendendo-a, criticando-a e transformando-a" (DAOLIO, 2006, p.89). São relevantes a seleção de temas contemporâneos que podem ser escolhidos com a participação dos alunos e desenvolvidos em uma aproximação com a esfera social e cultural, buscando a compreensão com conhecimentos elaborados e organizados, possibilitando ao aluno a aquisição de atitudes mais criteriosas em relação ao conhecimento do senso comum.

Nos dias atuais, com a difusão dos meios de comunicação de massa e sua utilização, como elemento de controle das amplas camadas populares, centrar-se nas análises das relações pedagógicas estabelecidas na escola, observando sua utilização como elemento de hegemonia e procurando "saídas" para uma escola realmente popular... (MARCELLINO, 2010, p. 42).

Associar o conteúdo físico-esportivo a uma perspectiva cultural, é compreender que esse fenômeno é produzido por sujeitos que partilham e atribuem significados, em uma dinâmica cultural, em processos de tensões e conflitos, que por vezes, se configuram em determinado pensamento, influenciado pelo meio que o indivíduo está inserido. Nesse contexto, as mídias, em especial, a internet, desempenham um papel de fundamental importância na construção do significado atribuído às práticas corporais pela sociedade.

O VAR é a sigla em inglês Video Assistant Referee que significa árbitro assistente de vídeo ou vídeo árbitro. Quando a partida é(ra) paralisada cria-se uma espécie de suspense em saber se o árbitro irá mudar a decisão, trazendo uma novidade à dinâmica de uma partida de futebol. 
[...] é surpreendente que a instituição escolar não tenha somente deixado que essa hegemonia na educação lhe fosse usurpada, mas que ainda assista, impassível, ao processo de penetração da cultura audiovisual, sem oferecer sequer modelos de interpretação e de análise crítica para as novas gerações (FERRÉS, 1996, p.10).

Cabe analisarmos criticamente a maneira como as práticas corporais são veiculadas na mídia, considerando a competência específica da disciplina de EF, relacionados a interesses voltados ao esporte, ao corpo, à ginástica, à lutas, à dança e outras práticas corporais disseminadas em nossa sociedade. O corpo, por exemplo, é valorizado sob o prisma de um modelo ideal de beleza, associado a interesses comerciais, onde a mídia é parte do percurso de convencimento aos indivíduos.

A educação para o lazer, coaduna com uma visão crítica criativa do lazer, que busca mudanças paradigmáticas, por meio de práticas educativas que possam contribuir com as transformações sociais que rompam com o modelo social predominante. Segundo Marcellino (2008, p. 26), nesta perspectiva:

A educação para o lazer pode ser entendida como um instrumento de defesa contra a homogeneização e internalização dos conteúdos veiculados pelos meios de comunicação de massa, atenuando seus efeitos, através do desenvolvimento do espírito crítico.

Dessa maneira, podemos considerar que há um aumento significativo do tempo que as pessoas ocupam utilizando (navegando) na internet via celular acessando temas explorados nas mídias, muitas vezes de forma superficial e fragmentada.

Uma educação para o lazer, questionadora, que suscita a criticidade, leva em conta, os conhecimentos que os alunos podem adquirir, tanto na prática, quanto na assistência, podendo esse gênero ser desenvolvido, em uma atitude ativa ${ }^{7}$ frente aos conteúdos físico-esportivos. "A cultura de "massa" (...) não é o estágio terminal ao qual espero conduzir os alunos da "minha" escola(...)" (SNYDERS, 1993, p.144).

Além de refletirmos sobre a necessidade de que o ambiente de aprendizagem seja propício para o desenvolvimento de um conhecimento sistêmico é necessário um equilíbrio entre satisfação e alegria na escola, superando os modismos, mas valorizando a utilização responsável de ferramentas pedagógicas que possam ser usadas com responsabilidade e protagonismo docente.

\section{CONSIDERAÇÕES FINAIS}

Parece inevitável que demandas socialmente estabelecidas caiam ou se entremeiem às discussões de assuntos considerados transversais ao conteúdo institucionalizado pelo currí-

7 Para Marcellino (2013) a atividade ativa ou passiva, não significa necessariamente a realização prática da atividade, podendo ser estabelecida conforme a atitude do indivíduo. Assim, a pessoa pode participar de alguma atividade, assistindo ou praticando um conteúdo cultural do lazer em três níveis: conformista, crítico e criativo. 
culo da educação básica, sobretudo da educação pública, onde por vezes é mais suscetível a assuntos cotidianos. Por si só, isso não parece algum problema, ou mesmo algo indesejado, haja vista o caráter vivo que se pretende dar ao currículo escolar, no entanto, quando determinados assuntos tendem a sobrepujar o próprio conteúdo, mas no caso da relação entre EF e o uso do aparelho telefônico, o esforço consciente de se resolver o problema deve ser de forma mais detida.

Constitui papel fundamental da EF escolar a análise de assuntos contemporâneos que têm implicações nas aulas e nos momentos de tempo disponível dos alunos. Alguns temas podem ser trabalhados criticamente, principalmente no Ensino Médio como oportunidade de ampliar o entendimento dos alunos para além do senso-comum. Cabe ao educador, além do incentivo da prática dos conteúdos físico-esportivos, também a formação de espectadores ativos, que possam analisar criticamente questões cotidianas que circulam de maneira restrita e fragmentada pela mídia.

A EF escolar pode e deve ser uma disciplina que contrapõe valores difundidos pela sociedade capitalista, oportunizando ações e conhecimentos que tensionem informações presentes nos veículos de comunicação e na sociedade de consumo. Atuando de modo que, o uso do celular na escola não seja o reflexo inconsciente e reprodutivo de seu uso na sociedade, à pena do processo de ensino-aprendizagem ser secundarizado por um momento de imobilismo educativo de conteúdos escolares, não oportunizando que o aluno se torne crítico e criativo.

Nesse sentido, algumas construções coletivas precisam ser pensadas no sentido de valorizar o diretivismo pedagógico, sem desconsiderar a busca de novas ferramentas de aprendizagem, desde que não minimizem a autoridade da escola e dos professores. Esse diretivismo a ser entendido como o próprio currículo, no entanto, deve ser dinâmico sem deixar de sê-lo enquanto elemento para um projeto de sociedade. Entendendo o currículo como uma política pública, o mesmo não pode deixar de ser aplicado, porém a forma de aplicá-lo dependerá muito do meio no qual ele está inserido.

Tal aplicação do currículo, demanda a observância de todos os envolvidos no processo ensino-aprendizagem como sujeitos, logo devem, alunos e professores serem munidos de autonomia para que o conhecimento pretendido seja de fato algo significante para ambos, sobretudo, para o aluno. A ressignificação só é possível por meio de uma curadoria a ser feita pelo professor, tanto de temas dentro do próprio conteúdo, quanto da metodologia a ser aplicada. Pensando como Jocimar Daolio, que a EF deve ser para todos, devemos compreender que o aluno não precisa necessariamente "Se" Movimentar, para se apropriar de um conhecimento da área de forma crítica e criativa. Parece-nos até recomendável que essa vivência não se limite a prática ou teórica, mas que se completem.

O que gostaríamos de deixar aqui é o uso do celular nas aulas de EF não deve ser proibido, mas ao contrário, ele deve ser discutido entre os sujeitos ali envolvidos. Principalmente acerca de suas possíveis utilidades, como já afirmado, existem inúmeros aplicativos nesse aparelho, logo seu uso consciente pode possibilitar uma ressignificação de sua relação com a EF. Um exemplo seria o de propor aos alunos filmar as aulas, ou ainda o uso 
de aplicativos que medem distância e calculam gasto energético, ganho de elevação no terreno entre outros dados, que podem ser utilizados em discussões teóricas sobre as práticas corporais. Pensando assim, diferentes grupos de alunos podem ser abordados acerca de um mesmo tema que esteja presente no currículo da EF.

O tema a que nos propomos explorar nesse ensaio, ainda apresenta uma produção teórica incipiente que carece de novas contribuições que poderão enriquecer próximas reflexões, pois se trata de um assunto (problema) recente que ocupou um espaço na sociedade contemporânea que como outros, sua resolução passa por uma discussão no âmbito escolar, uma vez que um não se encontra estanque do outro. Sendo assim, seria de grande valia estudos empíricos que discutissem o tema.

\section{REFERÊNCIAS}

BARCELOS, R. H. Nova Mídia, Socialização e Adolescência: Um estudo exploratório sobre o consumo da s novas tecnologias de comunicação pelos jovens. 2010. 231 s. Dissertação (Mestrado em Administração). Programa de Pós-Graduação em Administração, UFRGS, Porto Alegre, 2010.

BETTI, M. "Imagens em ação": Uma pesquisa-ação sobre o uso de matérias televisivas em programas de educação física do ensino fundamental e médio. Movimento, Porto Alegre, v.12, n. 2, p. 95-120, mai./ago., 2006.

Papirus, 2003.

A janela de vidro: Esporte, televisão e educação física. $2^{\mathrm{a}}$ ed. Campinas, SP:

BETTI, M.; LIZ, M. T. F. Educação Física escolar: a perspectiva de alunas do ensino fundamental. Motriz, Rio Claro, v. 9, n. 3, p. 135-142, set./dez., 2003.

BRACHT, V. Educação física \& ciência: cenas de um casamento (in)feliz. Ijuí: Editora Unijuí, 1999.

BRUHNS, H. T. O corpo parceiro e o corpo adversário. Campinas: SP: Papirus, 1999.

CAILLOIS, R. Os jogos e os homens: a máscara e a vertigem. Lisboa: Cotovia, 1990.

CARLAN, P. O esporte como conteúdo da educação física escolar: um estudo de caso de uma prática pedagógica. 2012. 354 s. Tese (Doutorado em Educação Física) Programa de Pós-Graduação em Educação Física, Centro de Desportos, UFSC, Florianópolis, 2012.

COMITÊ GESTOR DA INTERNET NO BRASIL. Pesquisa sobre o uso das tecnologias de informação e comunicação no Brasil: TIC Domicílios e Empresas. BARBOSA, A. F. (Coord.). São Paulo: 2017. Disponível em: http://data.cetic.br/cetic/ explore?idPesquisa=TIC_DOM. Acesso em: 19 set. 2018. 
CRUZ de OLIVEIRA, R. Na "periferia" da quadra - Educação Física, cultura e sociabilidade na escola. 2010. 201 s. Tese (Doutorado em Educação Física). Curso de Educação Física, Departamento de Educação Física, Unicamp, Campinas, 2010.

DAOLIO, J. Cultura: educação física e futebol. Campinas: Editora da Unicamp, 2006.

DARIDO, S. C. A educação física na escola e o processo de formação dos não praticantes de atividade física. Revista Brasileira de Educação Física e Esporte, São Paulo, v. 18, n. 1, p.61-80, jan./mar. 2004.

DAYRELL, J. O Jovem como sujeito social. Rev. Bras. Educ., n. 24, p.40-52, set./dez. 2003.

FERRÉS, J. Televisão e informação. Porto Alegre: Artes Médicas, 1996.

GADOTTI, M. História das ideias pedagógicas. São Paulo: Ática, 1993.

HARVEY, D. A condição pós-moderna: uma pesquisa sobre as origens da mudança cultural. São Paulo: Edições Loyola, 1989.

LUCKESI, C. C. Filosofia da Educação. São Paulo: Cortez, 1994.

LIBÂNEO, J. C. Didática. São Paulo: Cortez, 1994.

MARCELLINO, N. C. Lúdico e Lazer. In: MARCELLINO, N. C. (Org.). Lúdico, educação e educação física. Ijuí: Ed. Unijuí, 2013. p. 13-30.

. Lazer e Educação. Campinas: Papirus, 2010. 164p.

. Lazer e sociedade: algumas aproximações. In: MARCELLINO, N. C. (Org.). Lazer e sociedade: múltiplas relações. Campinas: Editora Alínea, 2008. p. 11-26.

. Lazer e cultura: algumas aproximações. In: MARCELLINO, N. C. (org.). Lazer e cultura. Campinas: Editora Alínea, 2007. p. 9-30.

MENDES, D. de S.; PIRES, G. de L. Desvendando a janela de vidro: relato de uma experiência escolar de mídia-educação e educação física. Rev. Bras. Cienc. Esporte, Campinas, v. 30, n. 3, p. 79-94, mai. 2009.

MINAYO, M. C. de S. Ciência, técnica e arte: o desafio da pesquisa social. In: MINAYO, M. C. de S. (org.). Pesquisa Social. Petrópolis, RJ: Vozes, 1994.

NAGUMO, E. O uso do aparelho celular dos estudantes na escola. 2014. 100 s. Dissertação (Mestrado). UNB. Faculdade de Educação. Programa de Pós-Graduação em Educação: Brasília, DF. 2014. 
NASCIMENTO, L. Cai o número de celulares em operação no país. Agência Brasil: Brasília, 2018. Disponível em: http://agenciabrasil.ebc.com.br/geral/noticia/2018-03/cai-o-numero-de-linhas-de-celular-em-operacao-no-pais. Acesso em 11 de set. 2018.

NÓVOA, A. Desafios do Trabalho do Professor no Mundo Contemporâneo. São Paulo: SINPRO (Sindicato dos Professores de São Paulo), 2007.

OLIVEIRA, C. de. MOURA, S. P. SOUSA, E. R. de. Tic's na educação: a utilização das tecnologias da informação e comunicação na aprendizagem do aluno. Pedagogia em ação. v. 7, n. 1, 2015.

SEVERINO, A. Metodologia Trabalho Científico. São Paulo: Cortez, 2007.

SNYDERS, G. Para Onde Vão as Pedagogias Não-Diretivas?, Lisboa/Portugal: Ed. Moraes, 1978.

TARDIF, M.; LESSARD, C. O Trabalho docente: elementos para uma teoria da docência como profissão de interações humanas. Petrópolis: Vozes, 2011.

TENÓRIO, J. G. Educação Física escolar, lazer e jogos desportivos coletivos: experiência no Ensino Médio. 2018. 158 s. Dissertação (Mestrado em Ciências do Movimento Humano), UNIMEP, Piracicaba, 2018.

TENÓRIO, J. G.; LOPES da SILVA, C. O desinteresse dos estudantes pelas aulas de educação física em uma escola de ensino público do estado de Mato Grosso. Salusvita, Bauru, v. 34, n. 1, p. 27-44, 2015.

. Educação Física Escolar e a não participação dos alunos nas aulas. Ciência em Movimento. Ano XV, n. 31, p. 71-80, 2013-2.

\section{Dados dos AUtores:}

\section{Jederson Garbin Tenório}

Mestre em Ciências do Movimento Humano pela Universidade Metodista de Piracicaba. Membro do Grupo de Estudo e Pesquisa em Lazer, Práticas Corporais e Cultura. Piracicaba/SP - Brasil. jederson.21@hotmail.com

Lucas de Andrade Carvalho

Mestre em Educação Física pela Universidade Metodista de Piracicaba. Membro do Grupo de Estudo e Pesquisa em Lazer, Práticas Corporais e Cultura. Diretor de unidade escolar da Prefeitura Municipal de Paulínia. Piracicaba/SP - Brasil. lucascarvalho2902@gmail.com

Submetido em: $30-10-2018$

Aceito em: 9-4-2019 